\title{
Biomarkery choroby Alzheimera w ślinie - przegląd piśmiennictwa
}

\author{
Biomarkers of Alzheimer's disease in saliva - a literature review
}

Katedra i Klinika Stomatologii Zachowawczej i Periodontologii

Uniwersytet Medyczny im. Karola Marcinkowskiego w Poznaniu

DOI: http://dx.doi.org/10.20883/df.2017.11

\begin{abstract}
Streszczenie
Choroba Alzheimera jest zaburzeniem neurodegeneracyjnym prowadzącym często do śmierci pacjenta. Charakterystycznym objawem tej choroby są zaburzenia pamięci, które spowodowane są zanikiem tkanki mózgowej. Wraz ze wzrostem średniej długości życia zapadalność na tę chorobę wzrasta. Praca stanowi przegląd piśmiennictwa dotyczącego możliwości wczesnej diagnozy choroby Alzheimera na podstawie analizy specyficznych białek (białka Tau i peptydu beta amyloidu 1-42-A 342 ) - biomarkerów pozyskiwanych ze śliny.
\end{abstract}

Słowa kluczowe: choroba Alzheimera, ślina, białko Tau, A $\beta 42$, zdrowie jamy ustnej.

\begin{abstract}
Alzheimer's disease is a neurodegenerative disorder, often leading to the death of the patient. Memory disorders are a haracteristic symptom of this disease, which are caused by a loss of brain tissue. With the increase in life expectancy the incidence of this disease has increased. This literature review concerns the possibility of the early diagnosis of Alzheimer's disease based on an analysis of specific protein (Tau protein and A $\beta 42$ ) biomarkers obtained from saliva.
\end{abstract}

Keywords: Alzheimer disease, saliva, Tau protein, oral health.

\section{Choroba Alzheimera}

W dobie szybkiego rozwoju nauk medycznych i możliwości wydłużenia życia pacjentów, badacze z całego świata stoją przed wyzwaniem znalezienia nowych metod diagnostycznych służących rozpoznawaniu coraz częściej występujących chorób, które pojawiają się wraz z wiekiem.

Jedną z głównych chorób, które występują w starzejącym się społeczeństwie, jest choroba neurodegeneracyjna, zwana chorobą Alzheimera. Po raz pierwszy została opisana przez niemieckiego neuropatologa Aloisa Alzheimera w roku 1906. Jest to najczęstsza w naszej populacji postać otępienia, a zarazem choroba śmiertelna. Najczęściej spotykana jest po 65. roku życia, lecz pierwsze objawy mogą wystąpić dużo wcześniej. Jest pierwotnie zwyrodnieniową chorobą mózgu spowodowaną odkładaniem się w nim patologicznych białek: $A \beta 42$, białka Tau i alfa-sunekleneiny, powodujących zanik neuronów i ich połączeń.

Według statystyk w 2006 roku na świecie cierpiało na nią około 26,6 miliona chorych, a przewiduje się, że do 2050 roku zachoruje jedna na 85 osób [1-3].

Choroba ma 3-fazowy przebieg kliniczny. W pierwszym, wczesnym etapie najczęściej moż- na już postawić diagnozę, a charakterystycznymi objawami są trudności w uczeniu się i zapamiętywaniu. Niekiedy pojawiają się też trudności językowe.

$\mathrm{Na}$ etapie umiarkowanym chorzy nie są w stanie samodzielnie wykonać codziennych czynności, stąd często pojawia się potrzeba opieki nad pacjentem. Narastają także trudności językowe. Chory może mieć trudności w rozpoznaniu najbliższych krewnych, znacznemu pogorszeniu ulega również pamięć długotrwała, która do tej pory pozostawała nienaruszona.

Etap zaawansowany to okres najtrudniejszy, w którym pacjent jest całkowicie zależy od opiekunów. Zanika masa mięśniowa, co często prowadzi do utraty możliwości samodzielnego poruszania się, następuje niemożność samodzielnego jedzenia. Ostatecznie choroba na tym etapie kończy się śmiercią pacjenta [4].

Przebieg choroby jest nieco odmienny u każdego pacjenta, natomiast istnieją pewne wspólne objawy. Wczesne symptomy, takie jak trudność w przypominaniu sobie niedawnych zdarzeń, często są błędnie wiązane $z$ wiekiem lub mogą być tłumaczone życiem w dużym stresie. Diagnozę potwierdzającą pierwotne rozpoznanie opiera się 
na testach oceniających zachowanie i zdolności kognitywne, a następnie - o ile istnieje taka możliwość - wykonuje się neuroobrazowanie.

Rozpoznanie powinno być postawione na podstawie podziału ICD-10 i włączone w jedną z grup, a mianowicie: G30.0 - Choroba Alzheimera o wczesnym początku (początek zwykle przed 65 r.ż.), G30.1 - Choroba Alzheimera o późnym początku (początek zwykle po 65 r.ż.), G30.8 - Otępienie typu alzheimerowskiego, G30.9 - Choroba Alzheimera, nie określona [5].

Ponadto DSM-IV (Diagnostic and Statistical Manual of Mental Disorders), stworzony przez American Psychiatric Association, mówi o najczęściej ulegających uszkodzeniu domenach kognitywnych, a mianowicie: pamięci, języku, percepcji, uwadze, zdolnościach konstruktywnych, orientacji, rozwiązywaniu problemów i zdolnościach funkcjonalnych. Jest to skala, w której należy ocenić zaburzenia kliniczne, zaburzenia osobowości, zaburzenia rozwojowe, stany ogólnomedyczne, psychospołeczne i środowiskowe oraz poziom przystosowania, co pozwala na zdiagnozowanie choroby, przewidywanie jej przebiegu, a także zaplanowanie postępowania [6].

Choroba u każdego pacjenta przebiega w sposób bardzo indywidualny, stąd postawienie właściwej diagnozy często jest problematyczne. Zanim choroba ujawni się w pełni, przebiega skrycie przez nieznany i zmienny okres. Potrafi $w$ takiej formie postępować przez lata bez rozpoznania. Średnia długość życia po postawieniu diagnozy wynosi 7 lat, natomiast mniej niż 3\% chorych przeżywa ponad 14 lat. Rozpoznanie choroby Alzheimera należy brać pod uwagę, kiedy pojawiają się problemy z tzw. pamięcią świeżą, czyli dotyczącą czynności wykonywanych aktualnie oraz na bieżąco nabywanych informacji. Wystąpienie tego rodzaju zaburzeń nie musi oznaczać ostatecznego rozpoznania, ale powinno skłonić osobę, której to dotyczy, do udania się do specjalisty [7, 8].

Istnieją pewne hipotezy, wskazujące czynniki ryzyka, które mogą zwiększać prawdopodobieństwo wystąpienia choroby Alzheimera. Hipoteza Tau zakłada, że proces chorobowy rozpoczyna się od nieprawidłowości białka Tau. Hiperfosforylowane nici białka Tau łączą się ze sobą, tworząc splątki neurofibrylarne wewnątrz ciał neuronów. Wynikiem tego jest dezintegracja mikrotubuli i niszczenie transportu neuronalnego, co powoduje upośledzenie funkcjonowania komunikacji biochemicznej pomiędzy neuronami, a w efekcie śmierć komórki [9].

Poza tym specyficzna izoforma apolipoproteiny, APOE4, należy do głównych genetycznych czynników ryzyka choroby Alzheimera. Apolipoproteina ma za zadanie zwiększać rozpad $\beta$-amyloidu, niektóre jednak jej formy, jak APOE4, nie spełniają tego zadania wystarczająco efektywnie, co skutkuje gromadzeniem się nadmiaru amyloidu w mózgu [10].

Z histopatologicznego punktu widzenia zatem charakterystycznymi cechami choroby jest $\mathrm{np}$. gromadzenie się amyloidu w mózgu, a także białka Tau w neuronach i komórkach glejowych.

\section{Badania diagnostyczne}

Diagnostyka choroby Alzheimera opiera się głównie na historii choroby pacjenta, wspartej specyficznymi testami i badaniami przesiewowymi, wywiadem rodzinnym, obserwacją kliniczną pacjenta. Ostateczne rozpoznanie stawia się najczęściej na podstawie diagnozy różnicowej, rozpoznania z wykluczenia, za pomocą np. tomografii komputerowej (CT) czy magnetycznego rezonansu jądrowego (MRI), a nawet pozytonowej tomografii emisyjnej (PET) i tomografii emisyjnej pojedynczego fotonu (SPECT). Badania te są niezwykle pomocne przy wykluczeniu innych przyczyn otępienia [11].

Jednym z badań przesiewowych jest krótka skala oceny stanu psychicznego (Mini Mental State Examination - MMSE) lub test zegara.

MMSE $[12,13]$ składa się z 30 pytań pozwalających na ilościową ocenę różnych aspektów funkcjonowania poznawczego. Obszary poddawane ocenie to: orientacja w czasie, orientacja w miejscu, zapamiętywanie, uwaga i liczenie, przypominanie, nazywanie, powtarzanie, rozumienie, czytanie, pisanie i rysowanie. Jest to test przesiewowy, którego przeprowadzenie ma na celu ocenę funkcji poznawczych. Podczas badania należy mieć pewność, że funkcje takie jak wzrok i słuch pacjenta działają na tyle sprawnie, że bez problemu może on wziąć udział w badaniu, słyszy i widzi wydawane mu polecenia i zadania. Jeśli zajdzie taka konieczność, należy umożliwić pacjentowi skorzystanie np. z aparatu słuchowego. Jeżeli podczas testu badający odniesie wrażenie, że któryś w powyższych powodów przyczynił się do udzielenia złej odpowiedzi, dane pytanie można powtórzyć najwyżej trzykrotnie. Za każdą prawidłową odpowiedź badany otrzymuje 1 punkt. Maksymalny wynik, jaki można uzyskać w teście, to 30 punktów.

Test zegara [14] polega na wydaniu pacjentowi polecenia narysowania zegara. Chorzy na Alzheimera najczęściej popełniają błędy, takie jak: brak wskazówki minutowej na rysunku, opuszczanie cyfr godzin, problemy z określeniem godziny, zaznaczenie godziny zamiast narysowania wskazówek. W zależności od stopnia zaawansowania choroby dane błędy w rysunku występują w róż- 
nym nasileniu, jednak prawidłowej oceny rysunku jest w stanie dokonać tylko specjalista.

Badania te jednakże nie są wystarczające do rozpoznania choroby, ale pozwalają z dużym prawdopodobieństwem wybrać osoby wymagające dalszej, precyzyjnej diagnostyki.

$\mathrm{U}$ około $2 \%$ rodzin $\mathrm{z}$ chorobą Alzheimera występuje tzw. postać o wczesnym początku (G 30.0), w której objawy pojawiają się przed 65 r.ż. Powodowana jest mutacjami $w$ genach preseniliny 1 (PSEN1), preseniliny 2 (PSEN2) lub genie prekursora beta-amyloidu (APP). Od 20 do $70 \%$ wczesnych postaci choroby związanych jest $z$ mutacją $w$ genie PSEN1. W 10-15\% przypadków mutacje dotyczą genu APP, a tylko sporadycznie występują w genie PSEN2. Istnieje możliwość wykonania molekularnego badania genetycznego w celu identyfikacji tych genów, polegającego na analizie eksonu 17 sekwencji kodującej gen APP. Istnieje również możliwość pobrania wymazu z policzka w celu wykrycia allelu ApoE4, który może zwiększać ryzyko wystąpienia choroby. Jest on także odpowiedzialny za predyspozycję do powstawania zmian miażdżycowych. Sam nie wywołuje choroby, natomiast wykrycie tego genu może przyspieszyć identyfikację $A D$ w czasie wystąpienia wczesnych objawów [15-17].

Powszechnie uznawany brak wczesnych protokołów diagnostycznych w chorobie Alzheimera oznacza, że rzadko rozpoznaje się ją przed wystąpieniem znacznej demencji klinicznej, a bez wczesnej diagnozy skuteczne leczenie choroby jest poważnie utrudnione.

\section{Markery diagnostyczne - wady, zalety i metody alternatywne}

Jednym z ogólnie uznanych za wrażliwe markery diagnostyczne choroby Alzheimera jest test wykrywający hiperfosforylowane białka Tau, całkowity poziom białka Tau i peptyd beta amyloidu 1-42 (Aß42) w płynie mózgowo-rdzeniowym [18-22].

Uzyskanie płynu mózgowo-rdzeniowego jest stosunkowo drogim, inwazyjnym zabiegiem, który wymaga udziału specjalnie przeszkolonych lekarzy. Trudności w pobieraniu płynu mózgowo-rdzeniowego powodują, że materiał ten nie jest idealnym źródłem próbki do badań przesiewowych i wczesnego diagnozowania choroby Alzheimera [23].

Ponadto pacjenci są poddawani testom inwazyjnym dopiero po odbyciu testów neuropsychologicznych, czyli w momencie, kiedy choroba jest już na tyle zaawansowana, że wykrywalne są pierwsze objawy związane z oczywistym pogorszeniem funkcji kognitywnych. Mogą one nie różnić się od zaburzeń wywołanych innymi procesami chorobowymi, w tym innymi typami demencji.
Nieodpowiednim materiałem do badań jest również osocze i surowica krwi. Płyny te były w przeszłości brane pod uwagę jako materiał diagnostyczny zdecydowanie łatwiejszy do pobrania i przeprowadzenia badań. Obecnie wyniki oznaczania poziomu $A \beta 42 \mathrm{w}$ osoczu nie są całkowicie jasne, dlatego rezygnuje się z wykorzystania tego płynu do badań. Białko Tau również nie jest wykrywalne w osoczu [24, 25].

\section{Poszukiwanie optymalnych biomarkerów}

Coraz więcej doniesień naukowych zwraca uwagę na metodę diagnostyczną pozwalającą w prosty sposób wykryć chorobę Alzheimera na wczesnym etapie, czyli nawet dekadę przed wystąpieniem pierwszych objawów. Dzięki temu możliwe jest wcześniejsze wprowadzenie farmakoterapii i oddziaływania psychospołecznego, stosowanego dodatkowo poza leczeniem farmakologicznym. Idealnym rozwiązaniem zatem wydaje się być poszukiwanie metod, które pozwolą różnicować chorobę Alzheimera z demencją innego typu już na etapie wystąpienia pierwszych objawów.

Liczne badania wskazują, że ślina zawiera biomarkery dla chorób neurodegeneracyjnych [26, 27]. Naukowcy odkryli patologiczne białka mózgu w ludzkiej ślinie, w tym $A \beta 42$ oraz hiperfosforylowane Tau w chorobie Alzheimera.

W 2010 roku zespół pod przewodnictwem Felixa Bermejo-Parejy [28] opublikował pracę pilotażową na podstawie badań prowadzonych na A 342 . Naukowcy podają, że znaleźli mały, ale istotny statystycznie wzrost stężenia w ślinie $A \beta 42 \mathrm{w}$ łagodnych postaciach u pacjentów z chorobą Alzheimera. Ponadto nie było różnic $w$ stężeniu w ślinie A 342 pomiędzy pacjentami z chorobą Parkinsona i zdrową próbą kontrolną. Związek pomiędzy poziomami $A \beta 42$ w ślinie i chorobą Alzheimera był niezależny od ustalonych czynników ryzyka, w tym np. wieku.

Badacze sugerują, że poziom $A \beta 42$ w ślinie może być uznany za potencjalny marker obwodowy choroby Alzheimera i pomóc rozróżniać ją z innymi typami chorób neurodegeneracyjnych.

Shi i wsp. wykonali badanie w grupie pacjentów z chorobą oraz w grupie osób zdrowych w celu oceny obecności hiperfosforylowanego białka Tau, całkowitego poziomu białka Tau i A 342 w ludzkiej ślinie. W tym celu wykorzystali metode immunoprecypitacji aby wzbogacić Tau i/lub A $\beta 42$ $w$ próbkach śliny $z$ zastosowaniem przeciwciał myszy, następnie użyli LTQ-Orbitrap (Spektrometr mas LTQ Orbitrap XL sprzężony z chromatografem cieczowym: to hybrydowy instrument pomiarowy posiadający pułapkę jonową oraz tzw. Orbitrap - analizator fourierowski, który nie wyma- 
ga stosowania kriocieczy dzięki użyciu pola elektrycznego), wykorzystując spektrometrię masową i zidentyfikowali pięć unikalnych białek Tau. Byli również w stanie zidentyfikować $A \beta 42$ w próbkach śliny przy użyciu tej metody [29, 30].

Wiadomo, że powstawanie charakterystycznych splotów w komórkach nerwowych u pacjentów z chorobą Alzheimera wymaga hiperfosforylacji Tau. Liczba i rozmieszczenie tych splotów neurofibrylarnych są obecnie używane do określenia etapu choroby. Shi i wsp. prezentują, że stosunek p-tau / T-tau znacznie wzrasta u pacjentów $z$ chorobą Alzheimera w porównaniu ze zdrowymi w próbie kontrolnej. Wykazano, że wraz z postępem choroby poziomy białka Tau w ślinie wykazują wzrost w postaci fosforylowanej. Badacze proponują możliwość wykorzystania biomarkerów Tau w ślinie nie tylko do diagnostyki, ale także w celu monitorowania postępu choroby Alzheimera i w odpowiedzi na terapię lekiem.

Inna grupa badawcza z Hospital Universitario 12 de Octubre w Madrycie, w Hiszpanii, wykonała szereg badań, głównie oceniających obecność i poziom $\beta 42$ zamiast Tau. Wykryto niewielki, ale istotny statystycznie wzrost $A \beta 42$ u pacjentów $z$ łagodną postacią choroby Alzheimera.

Naukowcy z Uniwerystetu Alberta w Kanadzie przedstawili wyniki swoich badań na Międzynarodowej Konferencji Stowarzyszenia Alzheimera w lipcu 2015 w Waszyngtonie. Analizowali próbki śliny osób, podzielonych na trzy grupy w zależności od zdolności poznawczych: 35 osób w zaawansowanym wieku z prawidłowym procesem poznania, $25 \mathrm{z}$ łagodnymi zaburzeniami poznawczymi i 22 z chorobą Alzheimera. Stosując technologię analizy białek, zbadali ślinę pacjentów, analizując prawie 6000 metabolitów. Wyniki badań wykazały obecność specyficznych biomarkerów (lub wzorców metabolitów) w grupach z rozpoznaną chorobą Alzheimera lub łagodnymi zaburzeniami poznawczymi, w porównaniu z grupą z objawami naturalnego starzenia. Badanie zostało zweryfikowane poprzez analizę nowej i niezależnej próby 27 kolejnych pacjentów, a prezentująca wyniki badań dr Shraddha Sapkota z Uniwersytetu Alberty w Kanadzie stwierdziła, że:

„Analiza metabolizmu śliny pozwala na wczesne wykrywanie choroby Alzheimera i polepsza nasze zrozumienie odróżnienia mechanizmów normalnego starzenia się do choroby Alzheimera" [31, 32].

\section{Podsumowanie}

Naukowcy są zgodni odnośnie rozwoju badań w kierunku rozpoznawania choroby Alzheimera na podstawie markerów takich jak białko Tau czy
A 342 w ślinie. Sam sposób pozyskiwania próbki diagnostycznej wydaje się być idealnym rozwiązaniem, zarówno u osób we wczesnym stadium rozwoju choroby, kiedy to poddanie się inwazyjnym zabiegom może być źle akceptowane, jak i u pacjentów z zaawansowaną chorobą Alzheimera, kiedy nawet proste zabiegi laboratoryjne, takie jak pobranie krwi, mogą powodować niepokój czy wręcz strach.

Byłby to prosty sposób wczesnego różnicowania choroby $z$ innymi jednostkami o podobnym obrazie klinicznym, a także perspektywicznie doskonały test przesiewowy.

Dlatego zasadne jest kontynuowanie badań nad wykorzystaniem testów ze śliny do diagnostyki choroby Alzheimera.

\section{Oświadczenia}

Oświadczenie dotyczące konfliktu interesów

Autorki deklarują brak konfliktu interesów w autorstwie oraz publikacji pracy.

\section{Źródła finansowania}

Autorki deklarują brak źródeł finansowania.

\section{Piśmiennictwo}

[1] Dubois B, Feldman HH, Jacova C, et al. Revising the definition of Alzheimer's disease: a new lexicon. Lancet Neurol. 2010;9:1118-1127.

[2] Dubois B, Feldman HH, Jacova C, et al. Research criteria for the diagnosis of Alzheimer's disease: revising the NINCDS-ADRDA criteria. Lancet Neurol. 2007;6:734746.

[3] What is Alzheimer's disease? Alzheimers.org.uk. Data dostępu: 8.2007.

[4] Förstl H, Kurz A. Clinical features of Alzheimer's disease. European Archives of Psychiatry and Clinical Neuroscience. 1999;249(6):288-29.

[5] http://apps.who.int/classifications/icd10/browse/2010/ en\#/G30.

[6] American Psychiatric Association: Diagnostic and statistical manual of mental disorders: DSM-IV-TR. 4th Edition Text Revision. Washington, DC: American Psychiatric Associatio; 2000.

[7] 2013 Alzheimer's disease facts and figures. Alzheimers Dement. 2013;9(2):208-9.

[8] Cummings JL. Alzheimer's disease. N Engl J Med. 2004;351(1):56-67.

[9] Goedert M, Spillantini MG, Crowther RA. Tau proteins and neurofibrillary degeneration. Brain Pathol. 1991;1(4):279286.

[10] Polvikoski T, Sulkava R, Haltia M, Kainulainen K, et al. Apolipoprotein E, dementia, and cortical deposition of beta-amyloid protein. N Engl J Med. 333 (19), 1995;11:12421247.

[11] Mendez MF. The accurate diagnosis of early-onset dementia. International Journal of Psychiatry Medicine. 2006;36(4):401-41

[12] Benson A, Slavin M, Tran TT, et al. Screening for Early Alzheimer's Disease: Is There Still a Role for the MiniMental State Examination? Prim Care Companion J Clin Psychiatry. 2005;7(2):62-69.

[13] O'Bryant S, Humphreys J, Smith G, et al. Detecting Dementia with the Mini-Mental State Examination (MMSE) in Highly Educated Individuals Arch Neurol. 2008 Jul;65(7): 963-967. 
[14] Vyhnálek M, Rubínová E, Marková H, et al. Clock drawing test in screening for Alzheimer's dementia and mild cognitive impairment in clinical practice. Int J Geriatr Psychiatry. 2016 Jul 28. doi: 10.1002/gps.4549.

[15] Waring SC, Rosenberg RN. Genome-wide association studies in Alzheimer disease. Arch Neurol. 2008;65(3):32934.

[16] Thordardottir S, Kinhult Ståhlbom A, Almkvist O. The effects of different familial Alzheimer's disease mutations on APP processing in vivo. Alzheimers Res Ther. 2017 Feb 16;9(1):9.

[17] Pagon RA, Adam MP, Ardinger HH, Seattle (WA): University of Washington, Seattle; 1993-2017. Bird TD, EarlyOnset Familial Alzheimer Disease.

[18] Hulstaert F, Blennow K, Ivanoiu A, et al. Improved discrimination of $A D$ patients using beta-amyloid(1-42) and tau levels in CSF. Neurology. 1999;52:1555-1562.

[19] Tang BL, Kumar R. Biomarkers of mild cognitive impairment and Alzheimer's disease. Ann Acad Med Singapore. 2008;37:406-410.

[20] de Jong D, Kremer BP, Olde Rikkert MG, Verbeek MM. Current state and future directions of neurochemical biomarkers for Alzheimer's disease. Clin Chem Lab Med. 2007;45:1421-1434.

[21] Hansson O, Zetterberg $\mathrm{H}$, Buchhave $\mathrm{P}$, et al. Association between CSF biomarkers and incipient Alzheimer's disease in patients with mild cognitive impairment: a followup study. Lancet Neurol. 2006;5:228-234.

[22] Mattsson N, Zetterberg H, Hansson O, et al. CSF biomarkers and incipient Alzheimer disease in patients with mild cognitive impairment. JAMA. 2009;302:385-393.

[23] Blennow KH, Hampel H. CSF markers for incipient Alzheimer's disease. Lancet Neurol. 2003;2:605-613.

[24] Song F, Poljak A, Smythe GA, Sachdev P. Plasma biomarkers for mild cognitive impairment and Alzheimer's disease. Brain Res Rev. 2009;61:69-80.

[25] Conrad C, Vianna C, Freeman M, Davies P. A polymorphic gene nested within an intron of the tau gene: implications for Alzheimer's disease. Proc Natl Acad Sci USA. 2002;99:7751-7756.

[26] Hui-Chong L, In-Kyu L, Pan-Woo K, et al. Non-Invasive Screening for Alzheimer's Disease by Sensing Salivary Sugar Using Drosophila Cells Expressing Gustatory Receptor (Gr5a) Immobilized on an Extended Gate IonSensitive Field-Effect Transistor (EG-ISFET) Biosensor
Published online 2015 Feb 25. doi: 10.1371/journal.pone.0117810.

[27] Ritter A, Cummings J, Fluid Biomarkers in Clinical Trials of Alzheimer's Disease Therapeutics. 2015 Aug 31. doi: 10.3389/fneur.2015.00186.

[28] Bermejo-Pareja F, Antequera D, Vargas T, et al. Saliva levels of Abeta1-42 as potential biomarker of Alzheimer's disease: a pilot study. BMC Neurology. 2010.

[29] Shi M, Sui YT, Peskind ER, et al. Salivary tau species are potential biomarkers of Alzheimer's disease. J Alzheimers Dis. 2011;27:299-305.

[30] Barthélemy NR, Fenaille F, Hirtz C, et al. Tau Protein Quantification in Human Cerebrospinal Fluid by Targeted Mass Spectrometry at High Sequence Coverage Provides Insights into Its Primary Structure Heterogeneity. J Proteome Res. 2016 Feb 5;15(2):667-76. doi: 10.1021/ acs.jproteome.5b01001.

[31] Anderson P. A Saliva Test for Alzheimer's Disease? Medscape Medical News. www.medscape.com. 2015 July 2.

[32] Lucas L. New saliva test may catch Alzheimer's disease early. CNN. www.cnn.com. 2015 July 2.

Zaakceptowano do edycji: 2017-04-20 Zaakceptowano do publikacji: 2017-14-25

Adres do korespondencji:

Katedra i Klinika Stomatologii Zachowawczej

i Periodontologii

ul. Bukowska 70, 60-812 Poznań

tel.: +48 618547026, +48 618547027

e-mail: marta_bekalarska@op.pl 